\title{
PREFERENSI KONSUMEN TERHADAP BAWANG MERAH LOKAL RUBARU DI PASAR BANASARE
}

\author{
Alwaniya * \\ Mahasiswa Prodi Agribisnis Fakultas PertanianUnija \\ Email: alwaniya002@gmail.com
}

\begin{abstract}
ABSTRAK
Bawang merah merupakan salah satu komuditi holtikultura yang berfungsi sebagai bumbu masakan serta obat tradisonal. Bawang merah varietas rubaru adalah bawang merah yang ada di kabupaten sumenep yang memiliki aroma yang tajam dan khas. Preferensi konsumen untuk mengukur pendapat konsumen terhadap bawang merah varietas rubaru. Tujuan dari penelitian untuk menganalisis preferensi konsumen terhadap atribut bawang merah yang berupa aroma, harga, dan bentuk di pasar banasare kecamatan rubaru, kabupaten sumenep. Populasi dalam penelitian ini semua konsumen bawang merah varietas rubaru. Metode pengambilan sampel menggunakan teknik Aksidentil sampling, ukuran sampel menggunakan teory roscue yaitu minimal sepuluh kali variebel, jumlah sampel penelitian 40 sampel. Analisis yang digunakan menggunakan analisis chi squre dan menggunakan pengukuran skala likert .hasil analisis menunjukkan hasil perhitungan chi square tabel lebih besar dari chi square hitung sehingga terdapat hubungan antara atribut aroma, harga, dan bentuk terhadap pembelian bawang merah varietas rubaru. Atribut yang dipertimbangkan konsumen yang pertama adalah aroma dengan hasil indeks persen $88 \%$, yang kedua harga dengan indeks persen $72,5 \%$ dan yang ketiga bentuk. Dengan indeks persen $62 \%$.
\end{abstract}

\section{Kata Kunci : , Bawang Merah Varietas Rubaru, Preferensi Konsumen}

\section{PENDAHULUAN}

Bawang merah adalah salah satu komoditi holtikultura yang banyak dikembangkan diindonesia yang memiliki peran penting untuk meningkatkan perekonomian. Bawang merah merupakan komoditi holtikultura yang tergolong dalam kategori komoditi bernilai tinggi (high value comodity). Menurut Litbang pertanian 2006, Bawang merah termasuk dalam kelompok rempah yang tidak memiliki rempah pengganti yang berfungsi sebagai bumbu penyedap makanan. Bawang merah ini tidak hanya sebagai penyedap rasa tetapi juga banyak mengandung manfaat bagi kesehatan. Bawang merah memiliki padat nutrisi yang rendah kalori yang bermanfaat sebagai vitamin, mineral, dan antioksidan.( Litbang Pertanian 2006).

Usahatani bawang merah dapat menjadi salah satu sumber pendapatan bagi petani dan, Pada saat ini usahatani bawang merah sudah tidak 
lagi berorientasi pada pemenuhan kebutuhan rumah tangga semata, tetapi sudah berorientasi pada usaha komersial. Hal ini dilakukan petani karena usahatani bawang merah lebih menguntungkan dibandingkan dengan usahatani pangan lainnya. Penghasil bawang merah di provinsi jawa timur bersentra pada daerah Nganjuk, Malang, Probolinggo, Bojonegoro, Sumenep, Sampang, Pamekasan, dan Mojokerto.

Kabupaten Sumenep merupakan salah satu sentra bawang merah yang memiliki Luas panen 46.999 Ha, Produktivitas 73,89 kw/Ha, dan Produksi 5.499 ton ( BPS,2017). Kecamatan Rubaru salah satu Kecamatan yang ada di Kabupaten Sumenep yang memproduksi bawang merah dengan luas 1.300 hektar. Pada tahun 2018, Menurut Sakdawi selaku penyuluh pertanian di Kecamatan Rubaru tingkat produksi bawang merah di kecamatan rubaru mencapai 8 ton/hektar dalam satu kali panen.

Preferensi konsumen berfungsi untuk mengetahui apakah barang atau jasa sesuai dengan keinginan konsumen. Hal hal yang dipertimbangkan konsumen dalam penentuan pembelian bawang merah biasanya didasarkan dengan atribut yang terkandung. Menurut Kotler dan Amstrong ( 2003) atribut produk dibedakan berdasarkan Kualitas, fitur, gaya dan desain, merek, kemasan, label dan pelayanan. Sedangkan Menurut Yani Fadhila (2017), Produk bawang merah memiliki beberapa atribut yang terkandung yaitu ukuran umbi/bentuk, harga, aroma, dan kelembapan/kekeringan bawang merah.
Dengan latar belakang diatas, tujuan penelitian ini untuk menganalisis preferensi konsumen terhadap bawang merah varietas Rubaru, berdasarkan atribut yang paling menentukan yaitu harga, aroma, dan bentuk.

\section{METODE PENELITIAN}

Penelitian ini dilakukan secara sengaja yaitu, di Pasar Banasare Kecamatan Rubaru, dengan pertimbangan bahwa di Kecamatan Rubaru adalah sentra bawang merah varietas Rubaru.

Pengambilan sampel ditentukan secara sengaja ( purposive), yaitu di pasar tradisional Banasare Kecamatan Rubaru kabupaten Sumenep, dengan pertimbangan bahwa di Pasar Banasare merupakan pasar yang paling besar yang ada di Kecamatan Rubaru.

Jumlah populasi dalam penelitian ini yaitu semua konsumen bawang merah varietas Rubaru di Pasar Banasare Kecamatan Rubaru Kabupaten Sumenep.

Metode penentuan sampel menggunakan teknik Sampling Accidentil. Sampel Accidentil merupakan teknik penentuan sampel berdasarkan konsumen yang bertemu langsung dengan peneliti dapat dijadikan sampel penelitian.

Menurut Roscoe 1982, dalam menentukan ukuran sampel penelitian jika peneliatian adalah multivarian, maka ukuran sampel menggunakan 10 $\mathrm{x}$ variabel. Dalam penelitian ini terdapat 1 variabel dependent (terikat) 
yaitu, Pembelian Bawang Merah dan 3 variabel independent ( bebas) yaitu, Aroma, Harga, dan Bentuk, maka jumlah sampel penelitian 10x4 = 40 sampel.

Metode

menggunakan Data Primer yaitu Observasi, wawancara, dan Kuisoener dan untuk data sekunder penelitian ini diambil dari internet, buku, dan dari hasil penelitian terdahulu yang berkaitan dengan penelitian.

\section{ANALISIS DATA}

Uji Chi Square

Analisis data yang digunakan

Tabel 1 : Nilai / Skor pada penelitian ini menggunakan analisis Chi Square dengan bantuan pengukuran Skala Likert.

Skala Likert merupakan alat ukur yang digunakan peneliti untuk mengukur variabel-variabel penelitian yaitu, Harga, Aroma, dan Bentuk. Berikut langkah-langkah dalam menggunakan skala likert adalah :

1. Mengumpulkan pertanyaanpertanyaan yang berkaitan dengan masalah yang akan diteliti. Alternatif jawaban berupa suatu tingkatan dari yang sangat tinggi hingga sangat rendah. Kemudian masing-masing jawaban diberi skor.

\begin{tabular}{lc}
\hline JAWABAN RESPONDEN & SK \\
\hline SangatSuka & 5 \\
Suka & 4 \\
Netral & 3 \\
TidakSuka & 2 \\
SangatTidakSuka & 1 \\
\hline
\end{tabular}

Total Skor $=$ T x Pn

$\mathrm{T}=$ Total jumlah responden yang

SKOR/NILAI

5

4

3

memilih

Pn = Pilihan angka skor Likert

2. Membuat skor total untuk setiap orang dengan menjumlah skor untuk semua jawaban.

a. Jumlah skor tertinggi $\mathrm{x}$ total responden

b. Jumlah skor terendah $\mathrm{x}$ total responden

3. Membuat indeks persen setiap atribut

Rumus Index $\%=$ Total Skor $/ \mathbf{Y} \mathbf{x}$ 100

Uji chi square $\left(\chi^{2}\right)$ digunakan oleh peneliti untuk mengukur adakah hubungan antara variabel yang dipertimbangkan konsumen dalam memilih bawang merah varietas Rubaru. Dan untuk jenis data yang

digunakan adalah data kategori atau data frekuensi.

Uji chi square, Berikut langkah-langkah dalam uji chi square :

1. Rumus uji chi square sebagai berikut :

$$
X^{2}=\sum_{i=1}^{k}\left[\frac{(f o-f e)^{2}}{f e}\right]
$$

$X^{2} \quad$ : Chi Square

fo : frekuensi yang diamati

fe : frekuensi yang diharapkan

$1 \ldots \mathrm{k}$ : kategori atribut dalam variabel bawang merah

Dimana :

$$
f e=\frac{R i \times C i}{\sum R i}
$$

Keterangan :

Ri : jumlah baris ke-ICi : jumlah 
kolom ke-I

$\sum \mathrm{Ri} \quad$ : jumlah pengamatan

Menguji hipotesis yang digunakan :

1) Formulasi hipotesis

$\mathrm{H}_{0}$ : Tidak terdapat hubungan antara atributharga, aroma, dan bentuk terhadap pembelian bawang merah varietas Rubaru.

$\mathrm{H}_{\mathrm{a}}$ : Terdapat hubungan atribut harga, aroma, dan bentuk terhadap pembelian bawang merah varietas Rubaru.

Taraf nyata atau signifikan $/ \alpha=5 \%=$ 0,05

2) Uji statistik dengan menggunakan rumus :

$$
X^{2}=\sum_{i=1}^{k}\left[\frac{(f o-f e)^{2}}{f e}\right]
$$

a. jika $\chi^{2}$ hitung $>\chi^{2}$ Tabel maka

$\mathrm{H}_{0}$ ditolak

b. jika $\chi^{2}$ hitung $\leq \chi^{2}$ Tabel maka $\mathrm{H}_{0}$ diterima

\section{HASIL DAN PEMBAHASAN}

Atribut Yang Dipertimbangka Konsumen Dalam Pembelian Bawang Merah Varietas Rubaru

Untuk mengetahui atribut bawang merah varietas Rubaru yang paling dipertimbangkan konsumen dalam pembelian bawang merah dengan mengunakan pengukuran Skala Likert.

Berikut hasil pengukuran menggunakan Skala Likert :

Keterangan :

fo : frekuensi pengamatan

fe : frekuensi harapan

3) Kriteria pengujian

Tabel 2 : Hasil Rekapitulasi Data Responden

\begin{tabular}{llll}
\hline Indeks & Harga & Aroma & Bentuk \\
\hline Sangat Suka & 7 & 20 & 8 \\
Suka & 15 & 16 & 6 \\
Netral & 12 & 4 & 14 \\
Tidak Suka & 6 & 0 & 8 \\
Sangat Tidak Suka & 0 & 0 & 4 \\
\hline Jumlah & 40 & 40 & 40 \\
\hline
\end{tabular}

Sumber : Data diolah 2019

Konsumen dalam menilai dimasukkan pada rumus indeks persen, yang akan disajikan pada Tabel 3.

setiap atribut bawang merah varietas

Rubaru memiliki respon yang berbeda beda. Adapun hasil dari responden yang diteliti ada yang menjawab Sangat suka, Suka,, Netral, Tidak Suka ,dan Sangat Tidak Suka. Untuk mengetahui Atribut yang paling dipertimbangkan oleh konsumen, 
Tabel 3 : Rekapitulasi Hasil Indeks Persen

\begin{tabular}{ll}
\hline Atribut & Indeks Persen \\
\hline Aroma & $88 \%$ \\
Harga & $71,5 \%$ \\
Bentuk & $63 \%$ \\
\hline
\end{tabular}

Sumber : Data Diolah 2019

Berdasarkan Tabel 3 di atas atribut yang paling dipertimbangkan oleh konsumen :

\section{Aroma}

Berdasarkan hasil Tabel 3 diatas, atribut Aroma adalah atribut yang paling dipertimbangkan konsumen terhadap pembelian bawang merah varietas Rubaru dengan hasil indeks persen $88 \%$. Aroma Bawang merah ini dipengaruhi oleh zat Piruvat, Sehingga dapat mengeluarka aroma yang khas, Bawang merah Varietas Rubaru ini memiliki aroma yang tajam yang khas dan gurih, sehingga membuat bumbu masakan lebih harum. Semakin harum bumbu masakan maka akan semakin enak masakan yang dibuat sehingga dapat menambah nafsu makan.

\section{Harga}

Setelah atribut Aroma, Atribut yang dipertimbangkan konsumen dalam pembelian bawang merah adalah harga dengan hasil indeks persen $71,5 \%$. Harga merupakan sejumlah nilai atau uang yang dibebankan atas suatu produk atau jasa untuk jumlah dari nilai nilai yang ditukar konsumen atas manfaat-manfaat harga yang telah menjadi faktor penting yang mempengaruhi pilihan pembeli. (Philip Kotler). Setiap produk barang atau jasa yang sama memiliki tingkat harga yang berbeda-beda. Harga bawang merah lokal lebih mahal dibandingkan dengan harga bawang merah impor. Berdasarkan hasil penelitian harga bawang merah varietas Rubaru yaitu sebesar Rp. 30,.000/kg, dan untuk harga varietas lain sebesar $\mathrm{Rp}$ $24.000 / \mathrm{kg}$. Varietas lain yang ada di Pasar Banasare adalah varietas yang berasal dari daerah Jawa Timur.

3. Bentuk

Setelah harga atribut bentuk yang menjadi pertimbangan konsumen dalam pembelian bawang merah dengan hasil indeks persen $63 \%$. Bentuk merupakan wujud yang ditampilkan yang tidak dibatasi oleh perbedaan dan tidak berubah saat parameter. Berdasarkan hasil penelitian Bawang merah varietas Rubaru memiliki bentuk ujung umbi sangat lonjong, dan pangkal umbi bulat lonjong, dan bentuk umbi lebih padat sehingga daya simpan bawang merah varietas rubaru ini lebih tahan lama. 
Hubungan Antara Atribut Harga, Aroma, dan Bentuk Terhadap Bawang Merah Varietas Rubaru.

Uji chi Square $\left(X^{2}\right)$ adalah analisis data yang digunakan untuk mengetahui ada dan tidaknya hubungan antara atribut bawang merah terhadap pembelian bawang merah varietas Tabel 4: Hasil Perhitungan Chi Square
Rubaru. Analisis chi square adalah mengetahui frekuensi observasi dan frekuensi harapan, dan data yang digunakan data nominal. Berikut hasil perhitungan akan disajikan pada Tabel 4.

\begin{tabular}{|c|c|c|c|c|c|c|}
\hline INDEKS & Atribut & $\mathrm{F}_{0}$ & $\mathrm{~F}_{\mathrm{h}}$ & $\mathrm{F}_{0}-\mathrm{F}_{\mathrm{h}}$ & $\left(\mathrm{F}_{0}-\mathrm{F}_{\mathrm{h}}\right)^{2}$ & $\left(\mathrm{~F}_{0}-\mathrm{F}_{\mathrm{h}}\right)^{2} / \mathrm{F}_{\mathrm{h}}$ \\
\hline \multirow{3}{*}{ Suka } & Harga & 2 & 6.325 & -4.325 & 18.71 & 2.96 \\
\hline & Aroma & 20 & 12.075 & 7.925 & 62.81 & 5.20 \\
\hline & Bentuk & 1 & 4.6 & -3.6 & 12.96 & 2.82 \\
\hline \multirow{3}{*}{ Netral } & Harga & 6 & 3.025 & 2.975 & 8.85 & 2.93 \\
\hline & Aroma & 1 & 5.775 & -4.775 & 22.80 & 3.95 \\
\hline & Bentuk & 3 & 2.2 & 0.8 & 0.64 & 0.29 \\
\hline \multirow{3}{*}{$\begin{array}{l}\text { Tidak } \\
\text { Suka }\end{array}$} & Harga & 3 & 1.65 & 1.35 & 1.82 & 1.10 \\
\hline & Aroma & 0 & 3.15 & -3.15 & 9.92 & 3.15 \\
\hline & Bentuk & 3 & 1.2 & 1.8 & 3.24 & 2.70 \\
\hline \multicolumn{6}{|l|}{$X^{2}$} & 25.10 \\
\hline
\end{tabular}

Sumber: Data Diolah 2019

Dari hasil perhitungan chi square hitung pada Tabel 4, sebesar 25,10. Dan Chi Square Tabel sebesar 9,448, dengan Df 4 dan taraf nyata 0,05 atau $5 \%$ dan kemudian dibandingkan Hasil Chi Square hitung dengan chi square Tabel. Untuk kriteria pengambilan keputusan yaitu jika $\chi^{2}$ hitung $>\chi^{2}$ Tabel maka $\mathrm{H}_{0}$ ditolak, dan jika $\chi^{2}$ hitung $\leq \chi^{2}$ Tabel maka $\mathrm{H}_{0}$ diterima. Berdasarkan hasil chi square hitung dan chi square Tabel yaitu chi square hitung lebih besar dari chi square Tabel maka $\mathrm{H}_{0}$ di tolak dan terima $\mathrm{H}_{\mathrm{a}}$ dan kesimpulan dari hasil uji chi square terdapat hubungan antara atribut harga, aroma, dan bentuk terhadap pembelian bawang merah varietas Rubaru.

\section{KESIMPULAN}

Berdasarkan hasil analisis yang telah dilakukan maka dapat disimpulkan :

1. Berdasarkan hasil analisis chi square, nilai chi square hitung lebih besar chi square Tabel maka $\mathrm{H}_{0}$ diterima dan tolak Ha, sehingga terdapat hubungan antara atribut harga,aroma dan bentuk terhadap pembelian bawang merah.

2. Atribut yang dipertimbangkan oleh konsumen dalam pembelian bawang merah varietas Rubaru adalah aroma.

\section{DAFTAR PUSTAKA}

Ammar,I. Asep,H.,dan Walim,L 2017 Analisis Preferensi Konsumen dalam Pengambilan Keputusan Membeli Produk Olahan Perikanan 
di Kota Tasik Malaya ( Studi kasus di pasar tradisional Cikurubug, Kec.Mengkubumi), Vol.VIII No 1/Juni 2017 (8-18)

Badan Litbang Pertanian 2006 Prospek dan Arah pengembangan Agribisnis Bawang Merah. Jakarta - badan Penelitian dan Pengembangan Pertanian kementerian Pertanian

Badan Pusat Statistik (BPS) Kabupaten Sumenep. 2016 Kecamatan Rubaru Dalam

Angkahttp://Sumenepkab.bps.go.id. Diakses pada tanggal 03 januari 2018

Badan Pusat Statistik Kabupaten Sumenep( Sumenep dalam Angka 2017 , Banyaknya Jumlah Penduduk, dan Jumlah desa di Kecamatan Rubaru, Kabupaten Sumenep.

Balai Pengkajian Teknologi Pertanian Jawa Timur Badan Penelitian dan Pengembangan Pertanian Kementrian Pertanian. 2014 ,Inovasi Teknologi Budidaya Dan Penanganan Hasil Bawang Merah Varietas Rubaru,

Kajian Pustaka. Pengertian, Unsur, dan Komponen Atribut Produk. http//www.kajianpustaka.com Kotler,Philip dan Armstrong 2012. prinsip-prinsip pemasaran. Jakarta: Erlangga.

Laporan Penelitian 2014. Analisis Chi Square Atau Chi Kuadrat. Http://tu.laporanpenelitian.com

Miftah,A.R.A. 2010. Analisis Proses Pengambilan Keputusan dan Preferensi Konsumen terhadap restoran Gurih 7 .Skripsi pada Program Sarjana Manajemen, Departemen Manajemen, Fakultas Ekonomi dan Manajemen. Institut Pertanian Bogor. http://repository.ipb.ac.id./handle/1 23456789/60219\&sa ) diakses pada tanggal 05 januari 2019.

Pusat Data dan Sistem Informasi Pertanian, 2016 Komuditas Pertanian Sub Sektor Hortikultura (bawang merah).

Rosselina, CK 2012 Analisis Preferensi Konsumen Yughuart My Healthy di Drama Bogor, Skripsi Fakultas Ekonomi dan Manajemen Institut Pertanian Bogor. http://repository.ipb.ac.id/jspui/bitr eam/123456789/56305/7/H12rck.

Sugiyono.2013. Metode Penelitian Kuantitatif Kualitatif dan $R \& D$.Bandung Alfabeta

Teknik Elektronika 2014. Pengertian Skala Likert Dan Cara Menggunakannya. Http://teknikelektonika.com 